\title{
Thermobarometric and Petrological Study of Mafic Xenolithes in Plagiogranites of the River Lotta Area of the Central Zone of the Lapland Granulite Belt
}

\author{
Butvina VG* and Safonov OG \\ Institute of experimental mineralogy (IEM) RAS, Chernogolovka, Russia \\ *Corresponding author: Butvina Valentina, Institute of experimental mineralogy \\ (IEM) RAS, Chernogolovka, Russia, Tel: 84965225851; Email: butvina@iem.ac.ru
}

\section{Research Article \\ Volume 2 Issue 3}

Received Date: March 06, 2018

Published Date: March 24, 2018

\section{Abstract \\ Thermobarometric data, fluid inclusions data and carbon isotope data confirm the conclusion that leucocratic garnet- bearing plagiogranites of the Lapland Granulite Belt (LGB) are associated with the anatexis of country khondalites during peak of metamorphism. The formation of these magmas occurred at depths of 25-30 km. During ascent, granitic magmas trapped mafic (two pyroxene-plagioclase) xenoliths at pressures 6.0-6.4 kbar. The interaction of predominantly aqueous- salt fluids issued by the magmas with the xenoliths during cooling at depths less than $20 \mathrm{~km}(5.0-5.5 \mathrm{kbar})$ led to their widespread amphibolization at temperatures of $740-780^{\circ} \mathrm{C}$.}

Keywords: Lapland Granulite Belt; The River Lotta Area; Granulite; Amphibolization; Thermobarometric data

Abbreviations: Ab: albite; Amph: amphibole; An: anorthite; Cherm: chermakite; Cpx: clinopyroxene; Ed: edenite; Opx: orthopyroxene, Pl: plagioclase; Parg: pargasite; Qtz: quartz; Tre: tremolite

\section{Introduction}

When studying the Lapland Granulite Belt (LGB), plagiogranites attract special attention, since they are formed at high P-T parameters and often carry information about the "peak" conditions of metamorphic mineral formation. Garnet and orthopyroxene plagiogranites within the LGB are confined to its northeastern part, forming large areas in the area of the Lotta and Lovnaozera rivers and extending westward to the Ivalo and further northern Norway [1]. With such a wide distribution of these rocks, the question of the origin of their protoliths has been little studied and, is, to the end, not elucidated. Here are a few points of view about the genesis of plagiogranites. Taking into account the similarity of the chemical and mineral composition of garnet plagiogranites and acid granulites, a number of authors considered them to be coarse-grained varieties of granulites.

In the future, the origin of synmetamorphic garnetbearing plagiogranites (1.917-1.909 Ga) of the River Lotta Area of the Central Zone of the Lapland Granulite Belt is associated with the anatexis processes of high-alumina metapelites (khondalites) of the complex at the peak of granulite metamorphism [1-4]. It should be noted, according to geological observations, the crystallization of plagiogranites from the melt is beyond doubt. This is indicated by finds within the granulite belt of the River 


\section{Petroleum \& Petrochemical Engineering Journal}

Lotta Area of the LGB of magmatic breccias, in plagiogranite cement of which fragments composed of the main rocks occur, among which plagiogranites are of particular interest, with the xenoliths of apogabbro-norite of granulite composition included. These mafic rocks against the background of a good study of the LGB are practically not investigated, but they play an important role in the genesis and synmetamorphic transformations of plagiogranites and can be a source of information about the origin of the melt and the nature of the interaction of rocks as the melt is raised. In connection with the above, the purpose of this work is to reveal the genesis of plagiogranites, based on a detailed petrologicmineralogical and thermobarometric study of the main xenoliths of plagiogranites in the River Lotta Area of the Central Zone of the LGB.

\section{Petrological and Mineralogical Study of Mafic Xenolithes}

\section{Analytical Methods}

The main methods for studying natural samples are: a) mineralogical and petrographic study using an Eclipse polarization microscope from Nikon LV100 POL; and b) electron microscopy and polarization analysis of samples on an electron microscope CamScan MV2300 (VEGA TS $5130 \mathrm{MM}$ ) equipped with a Link INCA Energy 450 energy dispersive microanalyzer and an Oxford INCA Wave 700 wave dispersion spectrometer at the IEM RAS, in lithosphere laboratory and physical research laboratory.

\section{Amphibolized Granulite}

Two-Pyroxene-Plagioclase

Xenoliths are uniformly grained rocks with a massive texture and granoblastic structure. Mineral composition: orthopyroxene $(20 \%)+$ clinopyroxene $(10 \%)+$ plagioclase $(40 \%)+$ amphibole $(15 \%) \pm$ quartz $(5-10 \%)+$ magnetite + ilmenite + pyrrhotite $(5-8 \%)+$ biotite + chlorite (less than $2 \%$ ).

The main minerals. The mafic xenoliths consist of lowzonal plagioclase $\left(30-40 \% ; \mathrm{An}_{47-54}\right)$, low-aluminous clinopyroxene $\left(10-15 \%, \mathrm{X}_{\mathrm{Mg}}=0.56-0.58,2-2.5 \%\right.$ by weight $\left.\mathrm{Al}_{2} \mathrm{O}_{3}\right)$ and orthopyroxene $\left(25-30 \% \mathrm{X}_{\mathrm{Mg}}=0.43\right.$ 0.44, 1-1.3 wt $\% \mathrm{Al}_{2} \mathrm{O}_{3}$ ) (Tables $1 \mathrm{a}, 1 \mathrm{~b}, 1 \mathrm{c}$ ). As a secondary mineral, amphibole is present. Accessory minerals. In the mafic xenoliths, 5-10\% quartz, accessory apatite, zircon as well as coexisting magnetite, ilmenite and pyrite and also pyrrhotite (sometimes sphalerite) occur.

Plagioclase, subidiomorphic tabular grains, up to $1 \mathrm{~mm}$ in size, extinction angles of 20-28, which corresponds to the composition of the plagioclase andesine-labrador, which is confirmed by analytical methods, not zonal or weakly zonal.

Orthopyroxene (hypersthene), subidiomorphic grains from 0.1 to $1 \mathrm{~mm}$, hypersthene pleochroism. It is replaced by a secondary amphibole with the formation of an ore mineral (Figures 1a \& 1b). Often fissuring of the orthopyroxene occurs, as well as the formation of the ore rim.

In the studied xenoliths, amphibolization processes are widespread in the form of wide rims of potassiumcontaining pargasite-edenite amphibole Figure 2 and its coarse-grained symplectites with quartz in the contacts of pyroxenes, magnetite, ilmenite and pyrrhotite with plagioclase. The more basic composition of the plagioclase and the lesser magnesia of the pyroxenes in the amphibolized sections of the xenoliths correspond to the amphibole formation: $\mathrm{Opx}+\mathrm{Cpx}+\mathrm{Ab}$ (in plagioclase) + $\mathrm{H} 2 \mathrm{O}=$ Amph \pm Qtz.

\begin{tabular}{|c|c|c|c|c|c|c|c|c|}
\hline №№ & $\mathbf{1 6}$ & $\mathbf{2 0}$ & $\mathbf{2 6}$ & $\mathbf{2 9}$ & $\mathbf{3 3}$ & $\mathbf{1 8}$ & $\mathbf{2 1}$ & $\mathbf{2 5}$ \\
\hline Com-nt & center & center & center & center & center & center & rim & rim \\
\hline $\mathrm{SiO} 2$ & 49,68 & 50,55 & 49,37 & 49,88 & 49,50 & 49,33 & 50,11 & 49,96 \\
\hline $\mathrm{TiO} 2$ & 0,17 & 0,14 & 0,07 & 0,00 & 0,31 & 0,00 & 0,00 & 0,14 \\
\hline $\mathrm{Al} 2 \mathrm{O} 3$ & 1,26 & 1,33 & 1,31 & 1,37 & 0,98 & 1,29 & 1,28 & 1,24 \\
\hline $\mathrm{FeO}$ & 32,93 & 31,77 & 32,66 & 32,29 & 32,18 & 32,50 & 32,26 & 32,26 \\
\hline $\mathrm{MnO}$ & 0,83 & 0,92 & 1,19 & 0,98 & 1,26 & 1,14 & 1,14 & 1,23 \\
\hline $\mathrm{MgO}$ & 14,56 & 14,58 & 14,56 & 14,41 & 14,66 & 14,36 & 14,59 & 14,20 \\
\hline $\mathrm{CaO}$ & 0,57 & 0,70 & 0,76 & 0,69 & 0,91 & 0,60 & 0,53 & 0,88 \\
\hline $\mathrm{Na} 20$ & 0,00 & 0,00 & 0,00 & 0,22 & 0,15 & 0,49 & 0,00 & 0,08 \\
\hline Total & 100,00 & 100,00 & 100,00 & 100,00 & 100,00 & 100,00 & 100,00 & 100,00 \\
\hline \multicolumn{7}{|c|}{ Formula units } \\
\hline Si & 1,96 & 1,98 & 1,95 & 1,96 & 1,95 & 1,95 & 1,97 & 1,97 \\
\hline
\end{tabular}

Butvina VG and Safonov OG. Thermobarometric and Petrological Study of Mafic Xenolithes in Plagiogranites of the River Lotta Area of the Central Zone of the Lapland Granulite Belt. Pet Petro Chem Eng J 2018, 2(3): 000150.
Copyright@ Butvina VG and Safonov OG. 


\section{Petroleum \& Petrochemical Engineering Journal}

\begin{tabular}{|c|c|c|c|c|c|c|c|c|}
\hline $\mathrm{Ti}$ & 0,01 & 0,00 & 0,02 & 0,00 & 0,01 & 0,00 & 0,00 & 0,00 \\
\hline $\mathrm{Al}$ & 0,06 & 0,06 & 0,06 & 0,05 & 0,06 & 0,06 & 0,06 & 0,06 \\
\hline $\mathrm{Fe}$ & 1,08 & 1,04 & 1,08 & 1,06 & 1,08 & 1,07 & 1,06 & 1,06 \\
\hline $\mathrm{Mn}$ & 0,03 & 0,03 & 0,04 & 0,03 & 0,04 & 0,04 & 0,04 & 0,04 \\
\hline $\mathrm{Mg}$ & 0,85 & 0,85 & 0,86 & 0,84 & 0,86 & 0,84 & 0,85 & 0,83 \\
\hline $\mathrm{Ca}$ & 0,02 & 0,03 & 0,03 & 0,03 & 0,04 & 0,03 & 0,02 & 0,04 \\
\hline $\mathrm{Na}$ & 0,00 & 0,00 & 0,00 & 0,02 & 0,01 & 0,04 & 0,00 & 0,01 \\
\hline
\end{tabular}

Table 1a: Electron microprobe analyses of orthopyroxenes from amphibolized two-pyroxene-plagioclase granulite of the River Lotta Area of the LGB.

*Note: Electron microprobe analyzes of minerals were performed in the IEM RAS on the Camscan microanalyzer.

\begin{tabular}{|c|c|c|c|c|c|c|c|c|c|}
\hline №o & $\mathbf{1 7}$ & $\mathbf{2}$ & $\mathbf{3}$ & $\mathbf{4}$ & $\mathbf{5}$ & $\mathbf{6}$ & $\mathbf{7}$ & $\mathbf{8}$ & $\mathbf{9}$ \\
\hline $\mathrm{SiO} 2$ & 49,98 & 50,55 & 49,81 & 50,49 & 49,99 & 50,71 & 50,18 & 50,68 & 50,33 \\
\hline $\mathrm{TiO} 2$ & 0,25 & 0,31 & 0,38 & 0,36 & 0,44 & 0,36 & 0,31 & 0,36 & 0,24 \\
\hline $\mathrm{Al} 2 \mathrm{O} 3$ & 2,23 & 2,28 & 2,12 & 2,21 & 2,13 & 2,41 & 2,22 & 2,09 & 2,26 \\
\hline $\mathrm{FeO}$ & 14,69 & 14,03 & 14,23 & 14,08 & 13,84 & 14,52 & 13,27 & 13,65 & 14,05 \\
\hline $\mathrm{MnO}$ & 0,54 & 0,86 & 0,64 & 0,69 & 0,39 & 0,50 & 0,45 & 0,33 & 0,47 \\
\hline $\mathrm{MgO}$ & 10,25 & 10,24 & 10,75 & 10,73 & 10,87 & 10,51 & 10,42 & 11,00 & 10,77 \\
\hline $\mathrm{CaO}$ & 21,20 & 21,43 & 21,50 & 21,04 & 21,58 & 20,64 & 22,24 & 21,40 & 21,11 \\
\hline $\mathrm{Na} 2 \mathrm{O}$ & 0,81 & 0,26 & 0,57 & 0,33 & 0,58 & 0,27 & 0,70 & 0,48 & 0,53 \\
\hline $\mathrm{Total}$ & 100,00 & 100,00 & 100,00 & 100,00 & 100,00 & 100,00 & 100,00 & 100,00 & 100,00 \\
\hline $\mathrm{Si}$ & 1,92 & 1,94 & 1,92 & 1,93 & 1,92 & 1,94 & 1,92 & 1,94 & 1,93 \\
\hline $\mathrm{Ti}$ & 0,01 & 0,01 & 0,01 & 0,01 & 0,01 & 0,01 & 0,01 & 0,01 & 0,01 \\
\hline $\mathrm{Al}$ & 0,10 & 0,10 & 0,10 & 0,10 & 0,10 & 0,11 & 0,10 & 0,09 & 0,10 \\
\hline $\mathrm{Fe}$ & 0,47 & 0,45 & 0,46 & 0,45 & 0,44 & 0,46 & 0,43 & 0,44 & 0,45 \\
\hline $\mathrm{Mn}$ & 0,02 & 0,02 & 0,02 & 0,02 & 0,01 & 0,02 & 0,01 & 0,01 & 0,02 \\
\hline $\mathrm{Mg}$ & 0,59 & 0,59 & 0,62 & 0,61 & 0,62 & 0,60 & 0,60 & 0,63 & 0,62 \\
\hline $\mathrm{Ca}$ & 0,87 & 0,88 & 0,89 & 0,86 & 0,89 & 0,84 & 0,91 & 0,88 & 0,87 \\
\hline $\mathrm{Na}$ & 0,06 & 0,02 & 0,04 & 0,02 & 0,04 & 0,02 & 0,05 & 0,04 & 0,04 \\
\hline
\end{tabular}

Table 1b: Electron microprobe analyses of clinopyroxenes from amphibolized two-pyroxene-plagioclase granulite of the River Lotta Area of the LGB.

*Note: Electron microprobe analyzes of minerals were performed in the IEM RAS on the Camscan microanalyzer

\begin{tabular}{|c|c|c|c|c|c|c|c|c|c|}
\hline №o & $\mathbf{3 5}$ & $\mathbf{3 6}$ & $\mathbf{3 7}$ & $\mathbf{3 8}$ & $\mathbf{3 9}$ & $\mathbf{4 0}$ & $\mathbf{4 1}$ & $\mathbf{4 2}$ & $\mathbf{4 3}$ \\
\hline Com-nt & center & rim & rim & center & center & center & center & center & center \\
\hline $\mathrm{SiO2}$ & 55,82 & 55,67 & 55,57 & 56,58 & 56,06 & 55,71 & 57,41 & 56,50 & 56,26 \\
\hline $\mathrm{TiO} 2$ & 0,00 & 0,04 & 0,14 & 0,08 & 0,09 & 0,00 & 0,21 & 0,06 & 0,00 \\
\hline $\mathrm{Al} 2 \mathrm{O} 3$ & 27,54 & 27,52 & 27,75 & 27,62 & 27,56 & 27,95 & 26,34 & 27,64 & 26,76 \\
\hline $\mathrm{FeO}$ & 0,24 & 0,17 & 0,20 & 0,00 & 0,04 & 0,06 & 0,26 & 0,32 & 0,46 \\
\hline $\mathrm{MnO}$ & 0,20 & 0,00 & 0,07 & 0,09 & 0,00 & 0,00 & 0,00 & 0,00 & 0,00 \\
\hline $\mathrm{MgO}$ & 0,14 & 0,05 & 0,20 & 0,01 & 0,14 & 0,20 & 0,11 & 0,09 & 0,29 \\
\hline $\mathrm{CaO}$ & 10,77 & 10,09 & 10,65 & 10,31 & 10,59 & 10,04 & 9,47 & 9,46 & 9,93 \\
\hline $\mathrm{Na} 2 \mathrm{O}$ & 5,10 & 6,12 & 5,25 & 5,12 & 5,29 & 5,83 & 5,84 & 5,66 & 6,15 \\
\hline $\mathrm{Total}$ & 100,00 & 100,00 & 100,00 & 100,00 & 100,00 & 100,00 & 100,00 & 100,00 & 100,00 \\
\hline $\mathrm{Si}$ & 2,51 & 2,50 & 2,50 & 2,54 & 2,52 & 2,50 & 2,51 & 2,53 & 2,53 \\
\hline $\mathrm{Ti}$ & 0,00 & 0,00 & 0,00 & 0,00 & 0,00 & 0,00 & 0,01 & 0,00 & 0,00 \\
\hline $\mathrm{Al}$ & 1,46 & 1,46 & 1,47 & 1,46 & 1,46 & 1,48 & 1,39 & 1,46 & 1,42 \\
\hline $\mathrm{Fe}$ & 0,01 & 0,01 & 0,01 & 0,00 & 0,00 & 0,00 & 0,01 & 0,01 & 0,02 \\
\hline
\end{tabular}

Butvina VG and Safonov OG. Thermobarometric and Petrological Study of Mafic Xenolithes in Plagiogranites of the River Lotta Area of the Central Zone of the Lapland Granulite Belt. Pet Petro Chem Eng J 2018, 2(3): 000150.
Copyright $(\mathrm{C}$ Butvina VG and Safonov OG. 


\section{Petroleum \& Petrochemical Engineering Journal}

\begin{tabular}{|c|c|c|c|c|c|c|c|c|c|}
\hline $\mathrm{Mn}$ & 0,01 & 0,00 & 0,00 & 0,00 & 0,00 & 0,00 & 0,00 & 0,00 & 0,00 \\
\hline $\mathrm{Mg}$ & 0,01 & 0,00 & 0,01 & 0,00 & 0,01 & 0,01 & 0,01 & 0,01 & 0,02 \\
\hline $\mathrm{Ca}$ & 0,52 & 0,49 & 0,51 & 0,49 & 0,51 & 0,48 & 0,45 & 0,45 & 0,48 \\
\hline $\mathrm{Na}$ & 0,44 & 0,53 & 0,46 & 0,44 & 0,46 & 0,51 & 0,51 & 0,49 & 0,54 \\
\hline
\end{tabular}

Table 1c: Electron microprobe analyses of plagioclases from amphibolized two-pyroxene-plagioclase granulite of the River Lotta Area of the LGB.

*Note: Electron microprobe analyzes of minerals were performed in the IEM RAS on the Camscan microanalyzer.

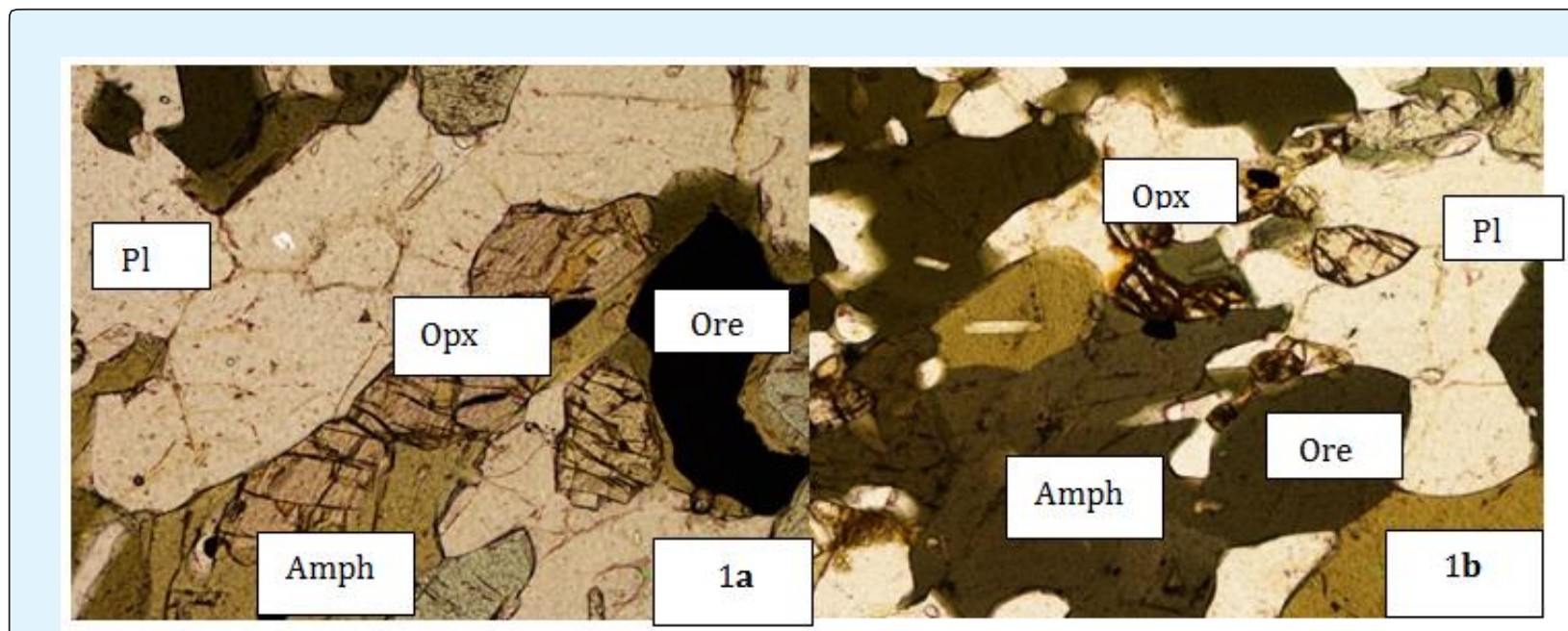

Figure 1a \& 1b: Photomicrographs of granulite samples and their reaction textures. All figures are 5 mm wide.

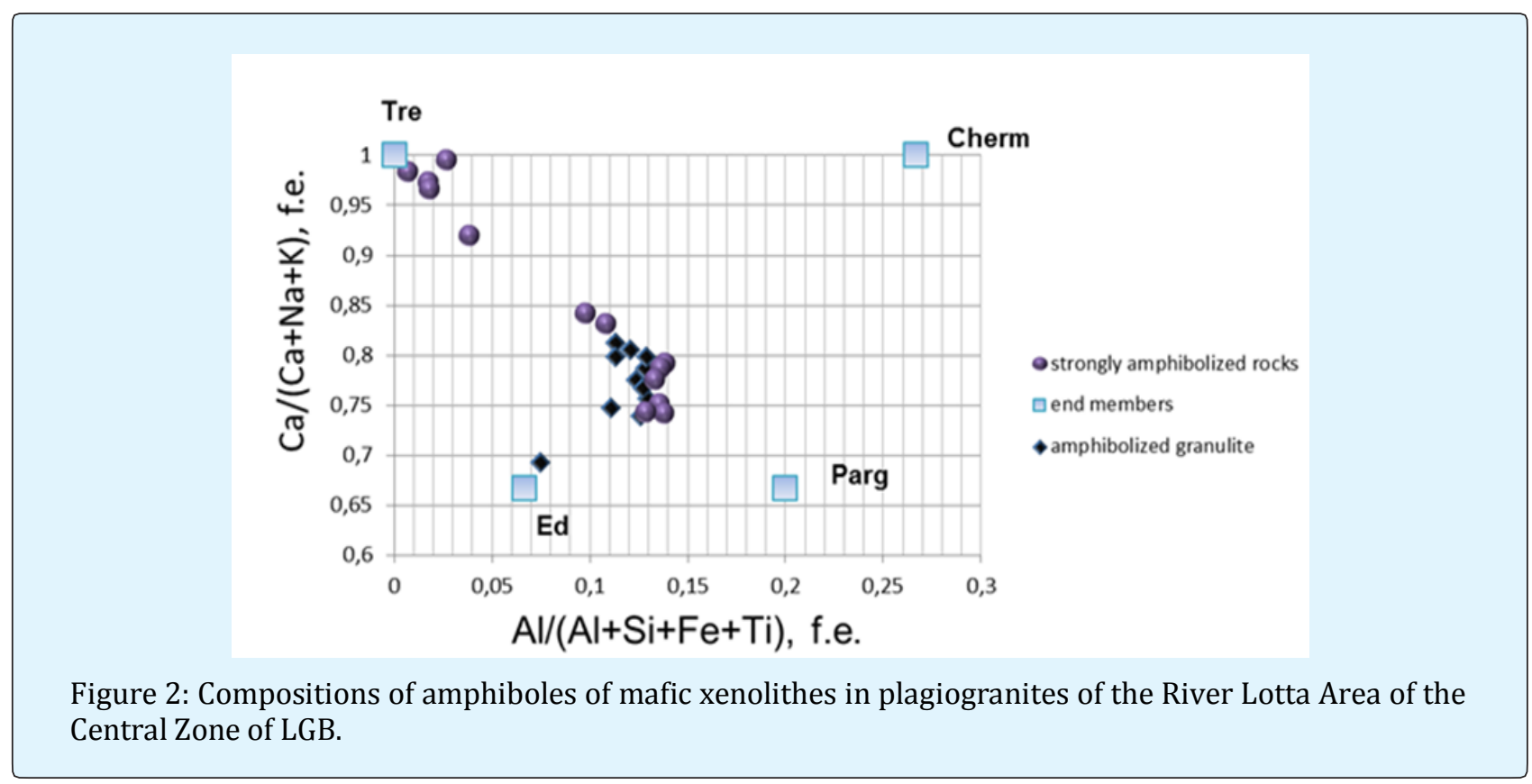

Amphibolization Figure $1 \mathrm{~b}$ is sometimes accompanied by the formation of biotite and ferruginization of the orthopyroxene along cleavage cracks and the formation of an ore mineral (magnetite \pm ilmenite \pm rutile), indicating 


\section{Petroleum \& Petrochemical Engineering Journal}

the addition of additional components to the xenoliths. Amphibole forms elongated (up to $2.5 \mathrm{~mm}$ in length) crystals with a ratio of width to length of $1: 3$ and forms reaction zones with orthopyroxene (Figure 1a), forms rims around the ore minera, (according to microanalysis is represented by two types of amphibole (Figure 2). Accessory minerals: zircon, apatite, magnetite, ilmenite and pyrite and also pyrrhotite (sometimes sphalerite).

\section{Thermobarometric Study of Mafic Xenolithes and the Discussion of the Results}

Using the TWQ 2.32 software package, a pressure of 6.0-6.4 kbar was estimated for equilibrium clinopyroxene + orthopyroxene + plagioclase + quartz in nonamphibolized sections of xenoliths (Table 2) [5]. The temperatures corresponding to this association are 800$860{ }^{\circ} \mathrm{C}$ and are within the crystallization temperature range of plagiogranites, as well as peak temperatures of the tectono-thermal stage M2 in the Lapland granulite belt $[3,4]$. The amphibole-plagioclase equilibrium recorded the temperatures of the process of amphibolization of xenoliths $740-780{ }^{\circ} \mathrm{C}$ at a pressure of 5.0-5.5 kbar 9 (Table 3) [6].

Based on certain thermodynamic conditions for the formation of the main xenoliths in the Lotta region of LGB, we can confidently confirm the assumption that the formation of plagiogranite magmas probably occurred at depths of the order of $25-30 \mathrm{~km}$. As they went up, they captured a variety of Xenoliths [1]. The results of new thermobarometric studies, data on fluid inclusions and isotope data for carbon in these rocks confirmed these conclusions $[7,8]$.

\begin{tabular}{|c|c|c|c|c|}
\hline Pl,№o & Opx,№№ & Cpx,№№ & T,C & P, kb \\
\hline $40^{*}$ & 16 & 9 & 804 & 6,2 \\
\hline 41 & 18 & 9 & 804 & 6,4 \\
\hline 43 & 20 & 17 & 862 & 6,0 \\
\hline 43 & 21 & 17 & 839 & 6,0 \\
\hline 38 & 29 & 6 & 802 & 6,2 \\
\hline 39 & 29 & 6 & 800 & 6,2 \\
\hline
\end{tabular}

Table 2: Thermodynamic conditions of equilibrium clinopyroxene + orthopyroxene + plagioclase + quartz in non-amphibolized sections of xenoliths, was estimated using the TWQ 2.32 software package [5].

*№ analysis, the compositions see Tables $1 \mathrm{a}, 1 \mathrm{~b}, 1 \mathrm{c}$

\section{Conclusions}

Using the TWQ 2.32 software package, a pressure of 6.0-6.4 kbar was estimated for clinopyroxene + orthopyroxene + plagioclase + quartz equilibrium in nonamphibolized sections of xenoliths [5].

\begin{tabular}{|c|c|c|c|c|c|c|c|}
\hline Amph,№o & $\mathbf{2 4 c}$ & $\mathbf{2 5 r}$ & $\mathbf{2 7 c}$ & $\mathbf{2 8 r}$ & $\mathbf{3 5 r}$ & $\mathbf{4 2 c}$ & $\mathbf{4 3 r}$ \\
\hline $\mathrm{SiO2}$ & 42,49 & 42,16 & 42,99 & 42,38 & 43,44 & 43,26 & 42,86 \\
\hline $\mathrm{TiO} 2$ & 1,71 & 1,32 & 1,88 & 1,71 & 0,80 & 1,34 & 1,57 \\
\hline $\mathrm{Al} 2 \mathrm{O} 3$ & 11,65 & 11,67 & 11,94 & 11,97 & 11,82 & 11,14 & 11,52 \\
\hline $\mathrm{FeO}$ & 20,59 & 20,34 & 20,37 & 20,98 & 19,67 & 19,90 & 20,81 \\
\hline $\mathrm{MgO}$ & 8,39 & 8,50 & 8,26 & 8,34 & 9,31 & 8,91 & 8,40 \\
\hline $\mathrm{MnO}$ & 0,38 & 0,28 & 0,35 & 0,13 & 0,33 & 0,31 & 0,29 \\
\hline $\mathrm{CaO}$ & 12,24 & 12,19 & 11,09 & 12,23 & 12,14 & 12,46 & 12,11 \\
\hline $\mathrm{Na} 2 \mathrm{O}$ & 1,47 & 1,35 & 1,44 & 1,14 & 1,16 & 1,56 & 1,21 \\
\hline $\mathrm{K} 2 \mathrm{O}$ & 1,25 & 1,32 & 1,29 & 0,95 & 0,99 & 1,24 & 1,10 \\
\hline $\mathrm{F}$ & 0,00 & 0,00 & 0,00 & 0,00 & 0,00 & 0,00 & 0,00 \\
\hline $\mathrm{Cl}$ & 0,00 & 0,00 & 0,00 & 0,00 & 0,00 & 0,00 & 0,00 \\
\hline $\mathrm{Sum}$ & 100,17 & 99,13 & 99,61 & 99,83 & 99,66 & 100,12 & 99,87 \\
\hline $\mathrm{Pl}$ & & & & & & & 0,53 \\
\hline $\mathrm{xAb}$ & 0,53 & 0,53 & 0,53 & 0,53 & 0,53 & 0,53 & 0,53 \\
\hline $\mathrm{xAn}$ & 0,47 & 0,47 & 0,47 & 0,47 & 0,47 & 0,47 & 0,47 \\
\hline $\mathrm{T}, \mathrm{C}$ & $\mathbf{7 6 6 , 3}$ & $\mathbf{7 5 6 , 0}$ & $\mathbf{7 7 9 , 9}$ & $\mathbf{7 6 2 , 9}$ & $\mathbf{7 4 5 , 6}$ & $\mathbf{7 3 9 , 9}$ & $\mathbf{7 6 0 , 4}$ \\
\hline $\mathrm{P}, \mathrm{kb}$ & $\mathbf{5 , 0 0}$ & $\mathbf{5 , 3 3}$ & $\mathbf{4 , 8 6}$ & $\mathbf{5 , 2 9}$ & $\mathbf{5 , 5 1}$ & $\mathbf{5 , 1 9}$ & $\mathbf{5 , 0 3}$ \\
\hline
\end{tabular}

Table 3: Thermodynamic conditions of granulite amphibolization process determined by means of amphiboleplagioclase equilibrium [6]. 


\section{Petroleum \& Petrochemical Engineering Journal}

Temperatures corresponding to the association, make $800-860^{\circ} \mathrm{C}$ and are within the crystallization temperature range plagiogranites, as well as peak temperatures tectonomagmatic thermal stage M2 Lapland's granulite belt $[3,4]$.
Clinopyroxene, xenomorphic grains from 0.1 to $1 \mathrm{~mm}$, occurs in paragenesis with plagioclase and orthopyroxene (Figure 3a).
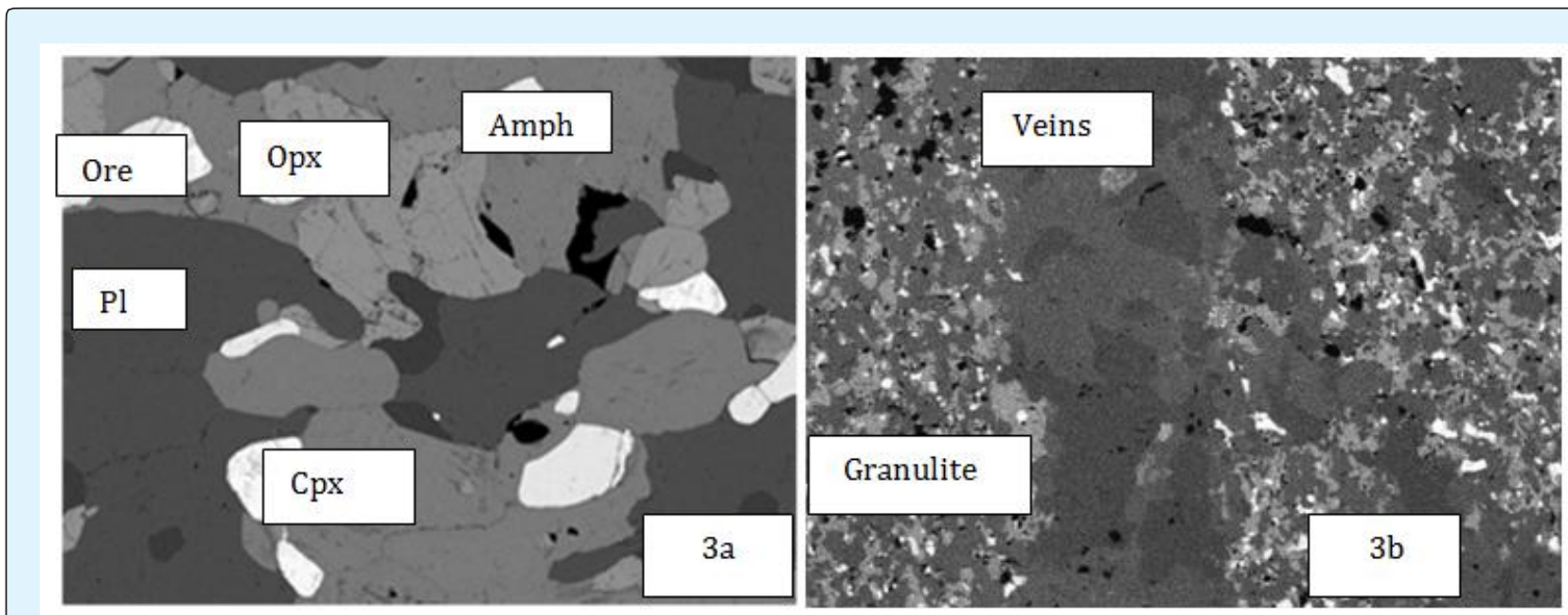

Figure 3a \& 3b: Electron microprobe photos of mineral paragenesis of granulite (3a) and veins of plagiogranite composition in it (Figure 3b).

Amphibole-plagioclase equilibrium recorded the temperatures of the process of amphibolization of xenoliths $740-780{ }^{\circ} \mathrm{C}$ at a pressure of 5.0-5.5 kbar [6]. Variations in the composition of the amphibole are in the direction of lowering the temperature. It was probably connected with the interaction of a substantially aqueous fluid from the cooling plagiogranite magma with xenoliths as they were captured and lifted. Indeed, the xenoliths are intersected by veins of plagiogranite composition (Figure $3 b)$. The abundance of water-salt $(12-20 \%$ by weight $\mathrm{NaCl}$ equivalent) inclusions and a subordinate amount of carbonaceous inclusions in minerals of plagiogranites confirms this assumption $[7,8]$.

\section{Acknowledgement}

Authors are greatful to Dr. Kaulina TV for provided samples of mafic xenolithes in plagiogranites of the River Lotta Area of the Central zone of the LGB. This work was supported by the Russian Foundation for Basic Research (grant 16-05-00266).

\section{References}

1. Kozlov NE, Kozlova NE (1998) On the Genesis of Pomegranate Plagiogranitoids of the Lapland
Granulite Belt. Bulletin of the Moscow State Technical University 1: 43-52.

2. Mitrofanov FP, Kravtsova EI, Manuilova MM (1974) Early Precambrian granitoid formations. Moscow, Science, pp: 292.

3. Mints MV, Kaulina TV, Konilov AN, Krotov AV, Stupak VM (2007) The thermal and geodynamic evolution of the Lapland granulite belt: Implications for thermal structure of the lower crust during granulite-facies metamorphism. Gondwana Research 12(3): 252-267.

4. Kaulina TV, Nerovich LI, Bayanova TB, Yapaskurth VO (2014) Sequence of geological processes in the Central and North-Eastern part of the Lapland granulite belt: isotope-geochemical data on zircon and the results of geological-petrological studies. Geochemistry 7: 625-645.

5. Berman RG (2007) WinTWQ (version 2.3): A software package for performing internally-consistent thermobarometric calculations. Geological Survey of Canada.

6. Blundy JD, Holland TJB (1990) Calcic amphibole equilibria and a new amphibole-plagioclase 


\section{Petroleum \& Petrochemical Engineering Journal}

geothermometer. Contribution to Mineralogy and Petrology 104(2): 208-224.

7. Safonov OG, Reutsky VN, Golunova MA, Butvina VG, Yapaskurt VO, Varlamov DA (2016) Different sources of carbon in granitoid fluids in granulite. Moscow, Russia.
8. Safonov OG, Reutsky VN, Golunova MA, Butvina VG, Yapaskurt VO, Varlamov DA, Shcherbakov VD, Van Rinnen DD (2017) Isotopic characteristics of carbon as an indicator of the source of high-temperature granitoids in granulite complexes. Proceedings of the Conference, Petrozavodsk, pp: 216-218. 